\title{
O019. Headache as an emergency in children and adolescents
}

\author{
Laura Papetti, Alessandro Capuano, Samuela Tarantino, Federico Vigevano, Massimiliano Valeriani* \\ From Abstracts from the 1st Joint ANIRCEF-SISC Congress \\ Rome, Italy. 29-31 October 2015
}

Pediatric and adolescence headache is one of the most common causes of access in Emergency Departments (ED). We reviewed the literature and we found that headache in ED is generally a benign condition that tends to be self-limited or resolves after an appropriate drug treatment. Causes of non-traumatic headache in ED include more frequently primary headaches $(21.8-66.3 \%)$ and secondary benign headaches (35.4-63.2\%), while secondary life-threatening headaches are less frequent (2-15.3\%) (Table 1). The most frequent worrying conditions include ventricoloperitoneal shunt malfunction, central nervous system infections, brain tumors, hydrocephalus, pseudotumor cerebri and hemorrhage. In a pediatric ED, the primary objective is to recognize the serious life-threatening conditions requiring immediate medical care among the wide spectrum of headache diagnoses. The diagnostic approach starts with a thorough history followed by a complete physical and neurologic examination. The temporal features may be useful to classify headaches into four temporal patterns (acute, recurrent acute, chronic progressive, chronic non-progressive) that aid in reaching the etiological diagnosis. A normal neurological examination has been demonstrated to highly correlate with the absence of relevant intracranial processes in several pediatric studies. Neuroimaging should be considered in patients with recent-onset severe headache or change in the type of headache or with associated signs or symptoms suggestive for intracranial diseases. The therapeutic management of headache in ED depends on general clinical conditions of the patients and the presumable etiology of headache [1].

Published: 28 September 2015

\section{References}

1. Papetti L, Capuano A, Tarantino S, Vigevano F, Valeriani M: Headache as an emergency in children and adolescents. Curr Pain Headache Rep 2015, 19(3):3.

2. Kan L, Nagelberg J, Maytal J: Headaches in a pediatric emergency department: etiology, imaging, and treatment. Headache 2000, 40(1):25-29.

3. Lewis DW, Qureshi F: Acute headache in children and adolescents presenting to the emergency department. Headache 2000, 40(3):200-203.

Table 1. Comparison of the studies about etiology of headache in ED * only patients with focal neurological signs at admission to ED

\begin{tabular}{|c|c|c|c|c|c|c|c|}
\hline & $\begin{array}{l}\text { Kan et al } \\
{[2]}\end{array}$ & $\begin{array}{l}\text { Lewis et al } \\
\text { [3] }\end{array}$ & $\begin{array}{l}\text { Leon-Diaz et al } \\
\text { [4] }\end{array}$ & $\begin{array}{l}\text { Conicella et al } \\
\text { [5] }\end{array}$ & $\begin{array}{l}\text { Burton et al } \\
{[6]}\end{array}$ & $\begin{array}{l}\text { Scagni et al } \\
{[7]}\end{array}$ & $\begin{array}{l}\text { Massano et al* } \\
{[8]}\end{array}$ \\
\hline Number of patients & 130 & 150 & 185 & 432 & 288 & 550 & 101 \\
\hline Age (years) & $>18$ & $>18$ & $2-15$ & $2-18$ & $2-18$ & $0-16$ & $6-18$ \\
\hline Secondary benign headaches (\%) & 63.2 & 59.6 & 60.5 & 35.4 & 63.2 & 38 & - \\
\hline $\begin{array}{l}\text { Secondary life-threatening } \\
\text { headaches (\%) }\end{array}$ & 15.3 & 14.9 & 4.3 & 4.1 & 2 & 4 & 9.9 \\
\hline Primary headaches (\%) & 10 & 18 & 24.3 & 24.5 & 21.8 & 56.7 & 66.3 \\
\hline Unclassified (\%) & 11.5 & 7 & 10.8 & 36 & 13 & 1.3 & 23.7 \\
\hline
\end{tabular}

\footnotetext{
* Correspondence: massimiliano.valeriani@opbg.net

Headache Centre, Division of Neurology, Ospedale Pediatrico Bambino Gesú,

Istituto di ricovero e cura a carattere scientifico, Rome, Italy
} 
4. Leon-Diaz A, Rabelino-Gonzalez G, Alonso-Cervino M: Analisis etiologico de las cefaleas desde un servicio de emergencia pediatrica. Rev Neurol 2004, 39:217-221.

5. Conicella E, Raucci U, Vanacore N, Vigevano F, Reale A, Pirozzi N, Valeriani $\mathrm{M}$ : The child with headache in a pediatric emergency department. Headache 2008, 48(7):1005-1011.

6. Burton $L$, Quinn B, Pratt-Cheney $\mathrm{JL}$, Pourani M: Headache etiology in a pediatric emergency department. Pediatr Emerg Care 1997, 13(1):1-4.

7. Scagni P, Pagliero R: Headache in an Italian pediatric emergency department. J Headache Pain 2008, 9(2):83-87.

8. Massano D, Julliand S, Kanagarajah L, Gautier M, Vizeneux A, Elmaleh M, et al: Headache with focal neurologic signs in children at the emergency department. J Pediatr 2014, 165(2):376-382.

doi:10.1186/1129-2377-16-S1-A142

Cite this article as: Papetti et al:: O019. Headache as an emergency in children and adolescents. The Journal of Headache and Pain 2015 16(Suppl 1):A142.

\section{Submit your manuscript to a SpringerOpen ${ }^{\odot}$ journal and benefit from:}

- Convenient online submission

- Rigorous peer review

- Immediate publication on acceptance

- Open access: articles freely available online

- High visibility within the field

- Retaining the copyright to your article

Submit your next manuscript at $>$ springeropen.com 